\title{
Optimization of Biosurfactant Production by Bacillus licheniformis Isolated from Oil Contaminated Egyptian Soil
}

\author{
E.M. Ramadan, Zeinb M. Kheiralla*, M.A. Foaad**, T.S. \\ EL-Tayeb and Eman Z. Goma** \\ Department of Agricultural Microbiology, Faculty of Agriculture, \\ Ain Shams University, Shoubra El-Kheima; Department of \\ Microbiology, Faculty of Women for Arts, Science \& Education, \\ Ain Shams University and ${ }^{* *}$ Department of Biological Sciences \& \\ Geology, Faculty of Education, Ain Shams University, Heliopolis, \\ Cairo, Egypt.
}

\begin{abstract}
( PTIMAL conditions for obtaining elevated biosurfactant production by a local strain of Bacillus licheniformis strain No. 5 were investigated. Modified minimal salt medium, $\mathrm{pH} 7.0$, containing crude oil (1\%), urea (2 g/l), $\mathrm{KH}_{2} \mathrm{PO}_{4}+\mathrm{K}_{2} \mathrm{HPO}_{4}(2+2 \mathrm{~g} / \mathrm{l}), \mathrm{MgSO}_{4}$ $(0.2 \mathrm{~g} / \mathrm{l})$, yeast extract $(1 \mathrm{~g} / \mathrm{l})$, and trace elements solution $(0.1 \%)$ was found to be the most suitable for growth and emulsifying activity by this bacterium. High biosurfactant production was obtained after incubation for 7 days at $30^{\circ} \mathrm{C}$. By providing the previous conditions, the emulsion index $\left(\mathrm{E}_{24} \%\right)$ was increased 3-fold as compared to that obtained via growth in the original minimal salt medium. In bioreactor batch culture, an agitation speed of $300 \mathrm{rpm}$ attained the highest microbial growth $(1.9 \mathrm{~g}$ cell dry weight $/ \mathrm{l})$ and an $\mathrm{E}_{24}=50.90 \%$ after 7 days of incubation. In fed-batch culture, the pulsed addition of crude oil during the first $2-3$ days of incubation enhanced the emulsification activity by 1.3 -fold. The greatest $\mathrm{E}_{24}$ was obtained using black grain oil $(89.09 \%)$, followed by that obtained against diesel oil $(87.27 \%)$. The highest stability of emulsion index was recorded on diesel oil, which remained stable for 10 days $\left(\mathrm{E}_{240}=81.81 \%\right)$. The biosurfactant showed an almost stable surface activity profile over a wide range of $\mathrm{pH}$ values (from 6 to 12). The maximum emulsification activity was obtained at $\mathrm{pH}$ 8. The reduction in $\mathrm{E}_{24}$ after exposure of the biosurfactant to $121^{\circ} \mathrm{C}$ for $15 \mathrm{~min}$ against diesel oil and toluene was $43.7 \%$ and $28.6 \%$, respectively. Chemical analyses of the purified biosurfactant showed that it is a lipoprotein. Significant emulsification activity was detected towards different aliphatic and aromatic hydrocarbons and vegetable oils. The purified biosurfactant contained $41.7 \% \mathrm{C}, 7.4 \% \mathrm{H}$ and $5.8 \% \mathrm{~N}$ and was comprised of $36.2 \%$ proteins, $12.3 \%$ lipids and $5.6 \%$ carbohydrates.
\end{abstract}

Keywords: Bacillus licheniformis, Biosurfactant production, Bioreactor, Emulsification, Lipoprotein, Hydrocarbons.

Microorganisms synthesize a wide variety of high and low molecular-mass biosurfactants (Mulligan, 2005). Microbial surfactants are a diverse group of surface-active compounds which have attracted considerable interest in recent years. Because of their surface-active properties, and environmentally benign

Contact author e-mail: tarekeltayeb@yahoo.com 
properties, biosurfactants are of great industrial and commercial interest. Potential commercial applications include detergent industry (Rosenberg \& Ron, 1998), petroleum, pharmaceutical, and food processing industries have the capacity to be manufactured from renewable and cheap substrates (Le Duc et al., 2004 and Cameotra \& Makkar, 2004). Furthermore, biosurfactants may be useful in agriculture, especially in the formulation of herbicides and pesticides. In this application, emulsifiers are used to disperse the active compounds and very hydrophobic molecules in aqueous solutions (Patel \& Gopinathan, 1986 and Rosenberg \& Ron, 1998). Biosurfactants have unique amphipathic properties derived from their complex structures, which include a hydrophilic moiety and a fuel hydrophobic portion. Biosurfactants produced by hydrocarbon-degrading microorganisms can emulsify hydrocarbon-water mixtures, which enables them to grow on oil droplets. These emulsification properties have also been demonstrated to enhance hydrocarbon degradation in the environment, making them potential tools for oil spill pollution remediation (Banat, 1995).

The emulsifying agents are produced only in the presence of the waterimmiscible substrates and appear to facilitate their metabolism (Makkar \& Cameotra, 2002). Fortunately, some indigenous microbes from chronically contaminated sediment may produce biosurfactants (Jonathan \& Urban, 2003). Most microbial surfactants are complex molecules, consisting of different structures that include lipopeptides, glycolipids, polysaccharide-protein complex, fatty acids, and phospholipids (Nitschke \& Pastore, 2006). The lipopeptides and glycoprotein are interesting classes of microbial surfactants (Walzer et al., 2006) because of a large number of attractive properties, the hydrophilic portion of biosurfactant can be a carbohydrate, amino acid, cyclic peptide, phosphate, carboxylic acid or alcohol. They can be potentially as effective with some distinct advantages over the highly used synthetic surfactants including high specificity, biodegradability and biocompatibility (Kanga et al., 1997). Fermentative production, composition and yields of biosurfactants by microorganisms depends primarily on the microbial strain, sources of carbon and nitrogen, $\mathrm{pH}$, temperature, oxygen concentration and metal ions in the growth medium (Mulligan \& Gibbs, 1993).

The studies described here were designed to optimize the production of biosurfactant by a local strain of Bacillus licheniformis strain No. 5 isolated from oil-contaminated soil. The study was extended to detect the biosurfactant activity under different stress factors.

\section{Materials and Methods}

\section{Biosurfactant-producing strain}

A selected strain of Bacillus licheniformis strain No. 5, which was previously isolated by these authors from an oil contaminated Egyptian soil (Ramadan et al., 2010) was used in the present study. The culture was grown on nutrient PYG agar slants (Rocha et al., 1992) and stored at $5^{\circ} \mathrm{C}$.

\section{Standard inoculum preparation}

The standard inoculum was prepared by transferring a loopful of a fresh slant culture of $B$. licheniformis strain No. 5 into $50 \mathrm{ml}$ of nutrient broth (PYG) medium

Egypt. J.Microbiol. 46 (2011) 
in $250 \mathrm{ml}$ Erlenmeyer flasks. The cultures were incubated, with shaking at $150 \mathrm{rpm}$, at $30^{\circ} \mathrm{C} \pm 2{ }^{\circ} \mathrm{C}$ for $48 \mathrm{hr}$. The produced culture $\left(5 \times 10^{7}\right.$ cell $\left./ \mathrm{ml}\right)$ was inoculated by the ratio of $5 \%(\mathrm{v} / \mathrm{v})$ as a standard inoculum (Sepahy et al., 2005).

\section{Biosurfactant production conditions}

For biosurfactant production, B. licheniformis strain No. 5 was grown aerobically on minimal salt medium (MSM) (Deziel et al., 1996) with the following composition (g/l): $\mathrm{MgSO}_{4} .7 \mathrm{H}_{2} \mathrm{O}, 0.2 ; \mathrm{CaCl}_{2} .2 \mathrm{H}_{2} \mathrm{O}, 0.02 ; \mathrm{KH}_{2} \mathrm{PO}_{4}, 1$; $\mathrm{K}_{2} \mathrm{HPO}_{4}, 1 ;\left(\mathrm{NH}_{4}\right)_{2} \mathrm{SO}_{4}, 1$ and $\mathrm{FeCl}_{3}, 0.05, \mathrm{pH}$ 7.0. Crude oil (the sole carbon source) was added at $0.5 \mathrm{ml} / 100 \mathrm{ml}$ of medium. Crude oil was obtained from Ennpi Petroleum Company, Nasr City, Cairo, Egypt. Five $\mathrm{ml}$ of the standard inoculum was introduced into $250 \mathrm{ml}$ Erlenmeyer flasks containing $100 \mathrm{ml}$ of medium and incubated in a shaking incubator $(150 \mathrm{rpm})$ at $30^{\circ} \mathrm{C} \pm 2{ }^{\circ} \mathrm{C}$. Biomass dry weight and biosurfactant production were determined after 9 days of incubation according to the method of Sifour et al. (2005). The emulsion index $\left(\mathrm{E}_{24} \%\right)$ was estimated according to the method of Verma et al. (2006).

\section{Effect of different culture conditions on biosynthesis of biosurfactant}

Growth and biosurfactant production were studied at different concentrations of crude oil $(0.25,0.5,1,1.5,2,2.5$ and $3 \mathrm{ml} / 100 \mathrm{ml})$, nitrogen sources $(0.25,0.5,1.0$, $1.5,2.0,2.5$ and $3.0 \mathrm{~g} / \mathrm{l}), \mathrm{KH}_{2} \mathrm{PO}_{4}+\mathrm{K}_{2} \mathrm{HPO}_{4}(0.5+0.5,1+1,2+2,3+3,4+4,2+1$ and $1+2 \mathrm{~g} / \mathrm{l}), \mathrm{MgSO}_{4}(0.1,0.2,0.3,0.4$ and $0.5 \mathrm{~g} / \mathrm{l})$, yeast extract $(0.25,0.5,1.0$, $1.5,2.0,2.5$ and $3.0 \mathrm{~g} / \mathrm{l})$, trace elements stock solution (Parks, 1997) $(0.05,0.1,0.2$, 0.3 and $0.4 \%)$. Incubation temperature $\left(20,25,30,35\right.$ and $\left.40^{\circ} \mathrm{C}\right)$ and different $\mathrm{pH}$ values $(4,5,6,7,8,9$ and 10) were also investigated. Triplicate sets of Erlenmeyer flasks were used for each treatment and the average, expressed as mean \pm standard error of triplicate determinations was recorded.

\section{Batch cultivation using bioreactor}

Small-scale batch cultivation was done in a dished bottom fermentor (Z6110/ coob, Cole-Parmer Instruments) which consisted of a 3 liter vessel (2 liter working volume) equipped with a lip seal stirrer assembly and automatic controllers for $\mathrm{pH}$, dissolved oxygen concentration and temperature. The culture temperature was adjusted to $30{ }^{\circ} \mathrm{C}$ during batch cultivations, and stirred at different agitation speeds $(100-500 \mathrm{rpm})$ at a constant aeration rate of $1.0 \mathrm{vvm}$. The medium $\mathrm{pH}$ was adjusted to 7.0 by the addition of $1 \mathrm{~N} \mathrm{NaOH}$ or $\mathrm{HCl}$ solutions (Joshi et al., 2007). Samples $(10 \mathrm{ml})$ were withdrawn every $24 \mathrm{hr}$ to determine growth and emulsifying activity.

\section{Pulsed supplementation of crude oil}

In this experiment, all nutritional requirements and environmental conditions which gave the maximum growth and emulsification activity were applied, except for supplementation with crude oil $(1 \%)$ that was introduced in pulsed doses. Crude oil (1\%) was divided into different equal amounts and added during 2, $3,4,5$ and 6 days of cultivation. The final working volume in the bioreactor was 21 at the end of feeding period. Microbial growth and emulsification activity were determined after 9 days of cultivation. 


\section{Extraction of crude biosurfactant}

After cultivation, bacterial cells were collected by centrifugation at $10,000 \times \mathrm{g}$ for $30 \mathrm{~min}$. The cell free supernatant was adjusted to $\mathrm{pH} 2$ using $6 \mathrm{~N} \mathrm{HCl}$ and kept for $24 \mathrm{hr}$ at $4^{\circ} \mathrm{C}$. The precipitate was collected by centrifugation at $15,000 \times \mathrm{g}$ for $30 \mathrm{~min}$ and the biosurfactant was extracted from the precipitate by using chloroform: methanol (2:1) (Kim et al., 1997). The organic solvents were evaporated to dryness under vacuum using a rotary evaporator and the weight of the biosurfactant was determined.

\section{Factors affecting the emulsification strength}

The stabilization of emulsions by the crude bioemulsifier was evaluated over a range of chemical and physical conditions. Crude biosurfactant solution was prepared by dissolving $(100 \mathrm{mg})$ crude extract in $10 \mathrm{ml}$ of $50 \mathrm{mM}$ Tris- $\mathrm{HCl}(\mathrm{pH} 8)$. Emulsion stabilization was tested using different hydrocarbons and oils. The crude biosurfactant solution $(3.5 \mathrm{ml})$ was added to a test tube containing $(2 \mathrm{ml})$ of the substrate (benzene, toluene, xylene, n-hexane, cyclohexane, kerosene, diesel oil, lubricating oil, corn oil, sunflower oil, olive oil, almond oil ,sesame oil, black grain oil , castor oil, or paraffin oil). The content of the tubes was vortexed at high speed for $2 \mathrm{~min}$ and left undisturbed for 10 days at room temperature. The emulsion index was determined at $24 \mathrm{hr}$ intervals. To test the effect of $\mathrm{pH}$ on emulsification activity, crude biosurfactant solution was prepared and adjusted to different $\mathrm{pH}$ values ranged from (2.0 to 12.0) using $1 \mathrm{~N} \mathrm{HCl}$ or $1 \mathrm{~N} \mathrm{NaOH}$ solutions, then incubated for $1 \mathrm{hr}$ at $30^{\circ} \mathrm{C}$. The emulsifying activity was determined by measuring the emulsion index $\left(\mathrm{E}_{24} \%\right)$ against toluene and diesel oil. For testing the effect of temperature on emulsifying activity, the crude biosurfactant solution was prepared and exposed to different temperatures $\left(20-100^{\circ} \mathrm{C}\right.$ for $1 \mathrm{hr}$ or $121^{\circ} \mathrm{C}$ for $\left.15 \mathrm{~min}\right)$. The emulsion index $\left(\mathrm{E}_{24} \%\right)$ was determined against diesel oil and toluene.

\section{Biosurfactant purification}

The crude biosurfactant was purified using preparative thin-layer chromatography (TLC) on silica gel plates (Whatman, Clifton, NJ), with a solvent system consisting of chloroform: methanol : acetic acid (65:25:4) according to Thaniyavarn et al. (2006).

\section{Analytical methods}

Carbon, Hydrogen and Nitrogen ratio were estimated by using an automatic elemental analyzer (Perkin-Elmer $2400 \mathrm{CHN}$ ). Total nitrogen and total lipids were determined according to the methods described in A.O.A.C. (1990), while total carbohydrates were determined by the phenol-sulfuric acid assay according to Chaplin \& Kennedy (1994). Amino acids of the purified biosurfactant were determined using an amino acid analyzer (Eppendorf Biotronik LC 3000 Amino Acid-Analyzer) according to the method of Pellet \& Young (1980). For the fractionation and estimation of fatty acids, the methylated samples of crude biosurfactant were fractionated and estimated by using GVC Pye Unicam gasliquid chromatography equipped with dual flame ionization detector and dual channel recorder (Sattler et al., 1996). 


\section{Results and Discussion}

Optimization of nutritional factors

Results from previous studies led to the conclusion that the biosurfactants produced by microorganisms in response to insoluble substrates (crude oil) can emulsify or disperse the oil phase into the water and make it available to the organisms (Bognolo, 1999). The present results indicated that $1 \%$ crude oil increased both the growth and the emulsifying activity of $B$. licheniformis strain No. 5 compared to control (Fig 1). Crude oil concentration above $1 \%$ had a negative effect on both growth and emulsification activity. The biosynthesis of the biosurfactant was growth associated. Likewise, Verma et al. (2006) used $1 \%$ oil as sole carbon source to study the ability of three bacterial strains, Bacillus sp., Acinetobacter sp. and Pseudomonas sp., to produce biosurfactant and degrade a complex mixture of petroleum hydrocarbons. The negative effect of the crude oil at the concentrations over $1 \%$ may be attributed to one of two factors. The first explanation is related to problems linked to the solubility of oil and the difficulty of the bacterium to gain access to the nutrients in the culture medium (Rashedi et al., 2005). A second hypothesis is related to the density of the hydrocarbon, since it forms a waxy layer. The formation of a floating waxy layer over the culture medium could adversely affect oxygen concentration and consequently lead to the sharp fall in biosurfactant production. This phenomenon likely leads to a reduction in the bacterial growth, as bacteria adhered to the bottom of the incubation flasks, producing a biofilm layer. Consequently, oil added to the flasks also functioned as a surface for bacterial adherence. Adherence reduced the numbers of free bacteria on the solution, followed by the interfering with bacterial cell quantification. Mineral oil has also been shown to reduce microbial growth and surfactant production in vitro, possibly by oxygen limitation (Krepsky et al., 2007).

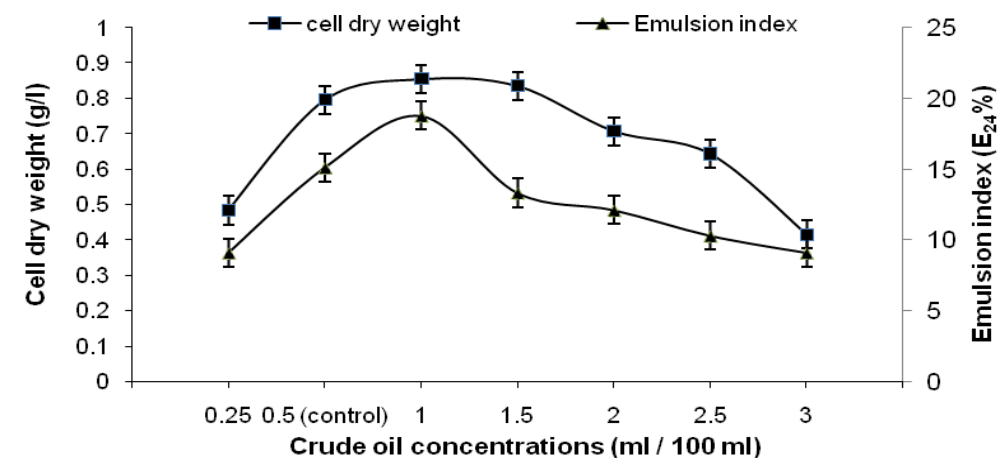

Fig.1. Effect of crude oil concentration on growth and emulsifying activity of $B$. licheniformis strain No. 5.

There is evidence that nitrogen plays an important role in the production of surface-active compounds by microorganisms. The type of nitrogen present $\left(\mathrm{NH}_{4}{ }^{+}, \mathrm{NO}_{3}{ }^{-}\right.$, urea, or amino acid) influences biosurfactant production (Haba et al., 2000 and Rismani et al., 2006). Four inorganic nitrogen sources (ammonium sulphate, ammonium chloride, ammonium nitrate, and sodium nitrate) and four organic nitrogen sources (ammonium acetate, casein, peptone and urea) were added separately to the minimal salt medium at different concentrations in order to

Egypt. J.Microbiol. 46 (2011) 
study the effect of different nitrogen sources on the growth and emulsifying activity of B. licheniformis strain No. 5. Results in Fig. 2 show that urea caused the highest emulsion index $(41.81 \%)$ at a concentration of $2 \mathrm{~g} / \mathrm{l}$. By increasing urea concentration more than $2 \mathrm{~g} / \mathrm{l}$, growth and emulsification activity decreased. These results are related to microbial growth rate (Fig. 3), and growth was increased with increasing urea concentration to reach the highest value by using $2 \mathrm{~g} / \mathrm{l}$ urea. These results are in accordance with that of Bonilla et al. (2005) who indicated that the emulsion index was greater when nitrogen was supplied at the oxidation level of ammonia (urea) than nitrate for the production of bioemulsifier by Pseudomonas putida. Urea was found to be more stimulative than ammonium sulphate (control) for biosurfactant production; this can be explained based on the metabolic point of view. Urea is not used in protein synthesis directly, but it can be acted upon by enzymes (deaminases, decarboxylases and aminotransferases) to release ammonia and make it available for biosynthesis. However, excessive initial concentrations of ammonium ions inhibit the pathways integrated in the biosynthesis of lipid fraction. Based on the above results, ammonium sulphate at a concentration of $1 \mathrm{~g} / \mathrm{l}$, was replaced by $2 \mathrm{~g} / \mathrm{l}$ urea in the MSM (containing $1 \%$ crude oil) as it enhanced the emulsification activity by 2.2 -fold.
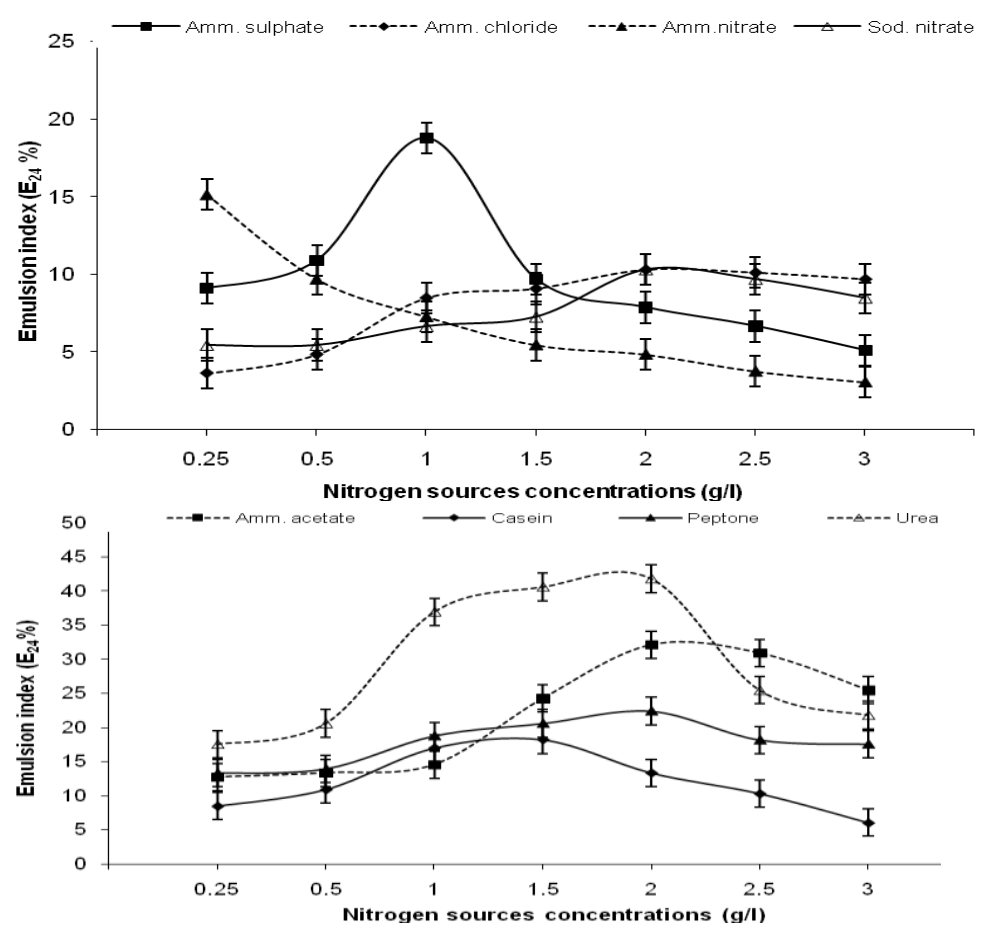

Fig. 2. Emulsion indexes $\left(E_{24} \%\right)$ of $B$. licheniformis strain No. 5 as influenced by different concentrations of nitrogen sources. 


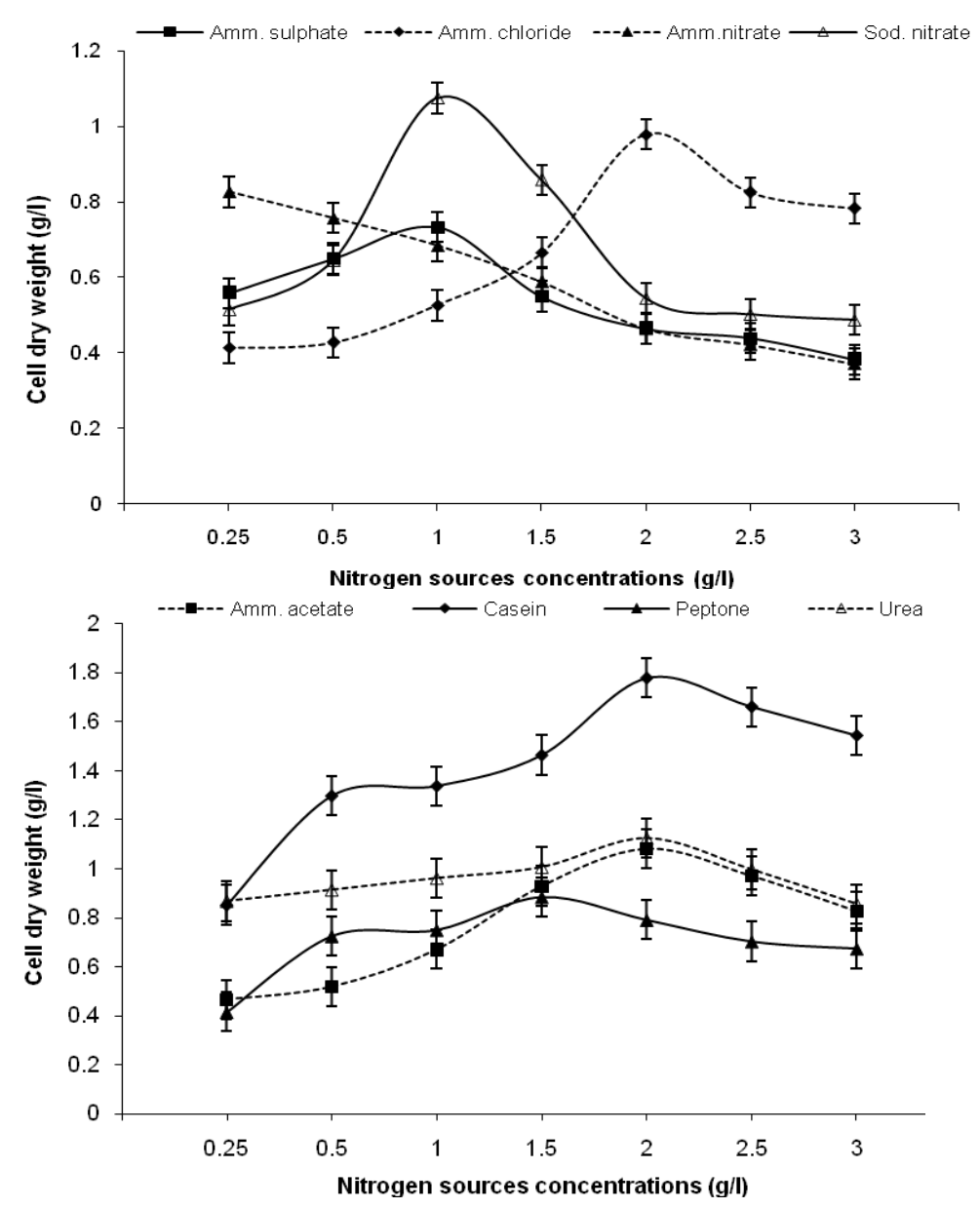

Fig. 3. Effect of different concentrations of nitrogen sources on growth of $B$. licheniformis strain No. 5.

In a separate study, growth and emulsifying activity were increased with increasing phosphate buffer concentration in the production medium (Fig. 4). Two gram/liter of each of $\mathrm{KH}_{2} \mathrm{PO}_{4}$ and $\mathrm{K}_{2} \mathrm{HPO}_{4}$ gave the highest cell dry weight $(1.328 \mathrm{~g} / \mathrm{l})$ and emulsion index $(42.42 \%)$. Increasing the concentration of phosphate more than this had a negative effect on the growth and emulsifying activity of $B$. licheniformis. Haddadin et al. (2009) reported that optimum amounts of biosurfactants were produced by Rhodococcus erythropolis and Rhodococcus rubber $\mathrm{w}$ then $\mathrm{K}_{2} \mathrm{HPO}_{4}(2 \mathrm{~g} / \mathrm{l})$ and $\mathrm{KH}_{2} \mathrm{PO}_{4}(1 \mathrm{~g} / \mathrm{l})$ were added to the growth medium. The effect of phosphorus sources can be explained by the buffering function of phosphate ions in preventing a decrease of $\mathrm{pH}$ values, which had a great influence on cell growth and consequently, biosurfactant production. 


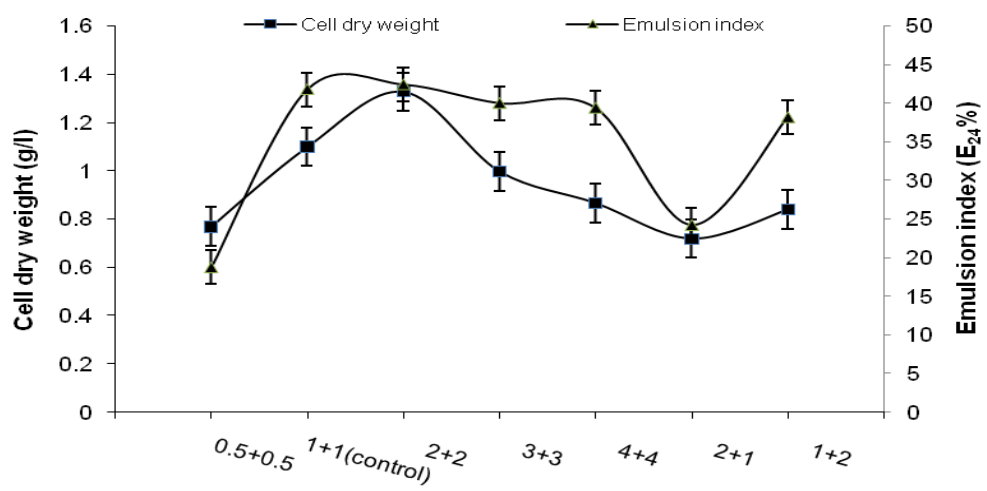

$\mathrm{KH}_{2} \mathrm{PO}_{4}+\mathrm{K}_{2} \mathrm{HPO}_{4}$ concentrations (g/l)

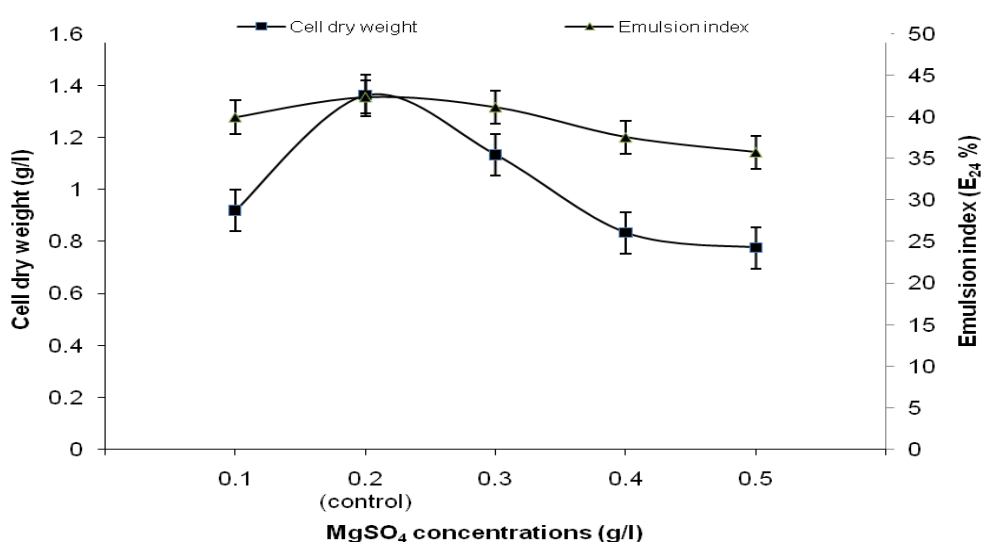

Fig. 4. Effect of different phosphorous sources or $\mathrm{MgSO}_{4}$ concentrations on growth and emulsifying activity of $B$. licheniformis strain No. 5 .

In contrast, changing the $\mathrm{MgSO}_{4}$ concentration did not affect the growth or emulsifying activity (Fig. 4). The optimum cell dry weight $(1.364 \mathrm{~g} / \mathrm{l})$ and emulsion index (42.42\%) were achieved using $0.2 \mathrm{~g} / 1 \mathrm{MgSO}_{4}$ (control). By increasing $\mathrm{MgSO}_{4}$ concentration more than $0.2 \mathrm{~g} / \mathrm{l}$, both growth and emulsion index decreased. Turkovskaya et al. (2001) indicated that the optimum conditions for growth and biosurfactant production by Pseudomonas aeruginosa required $\mathrm{Mg}^{2+}$. Also, Chen et al. (2007) indicated that the concentration of $\mathrm{MgSO}_{4}$ was the most significant factor affecting rhamnolipid production by Pseudomonas aeruginosa.

The concentration of yeast extract varied in modified MSM containing $1 \%$ crude oil, $2 \mathrm{~g} / \mathrm{l}$ urea, $2+2 \mathrm{~g} / \mathrm{l}$ of $\mathrm{KH}_{2} \mathrm{PO}_{4}+\mathrm{K}_{2} \mathrm{HPO}_{4}$ and $0.2 \mathrm{~g} / \mathrm{l} \mathrm{MgSO}$. Cell dry weight and emulsifying activity gave their highest values $(1.509 \mathrm{~g} / 1,43.02 \%)$ when $1.0 \mathrm{~g} / \mathrm{l}$ of yeast extract was used (Fig. 5). However, growth and emulsification activity decreased by increasing yeast extract concentration more than this value. 

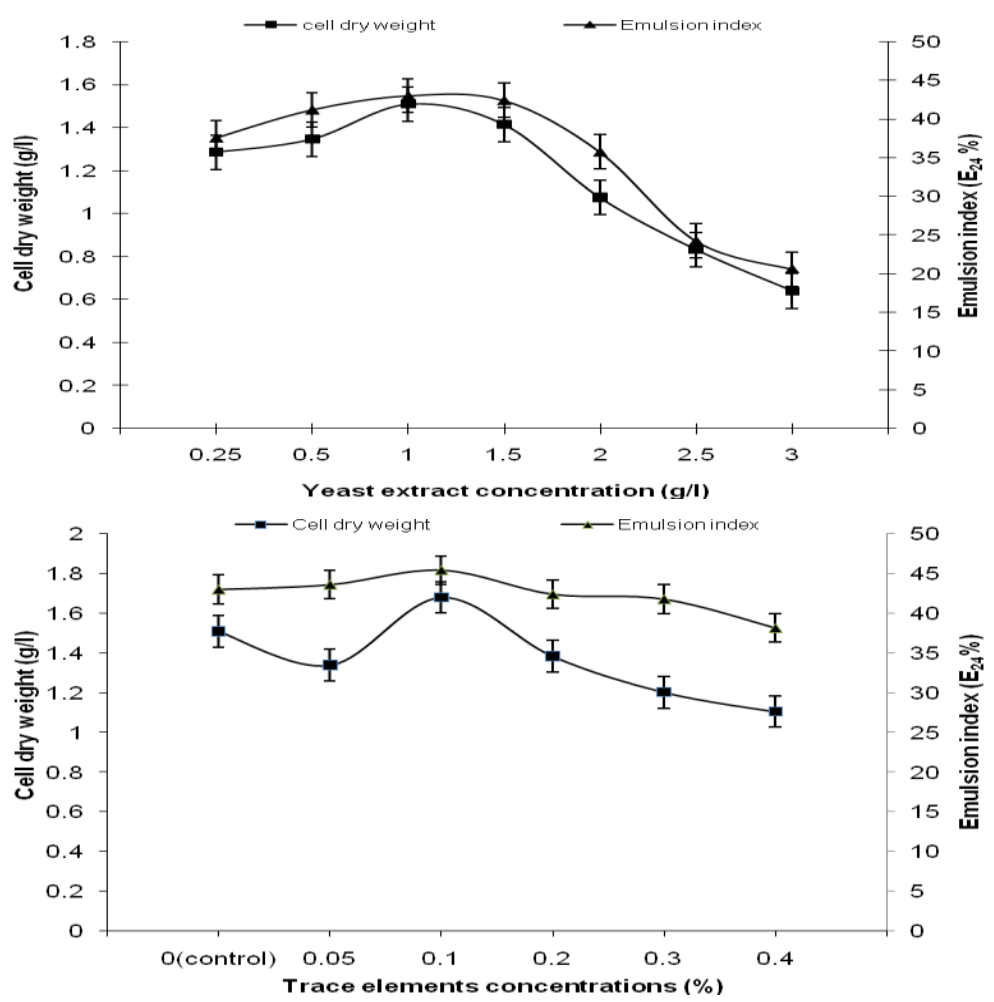

Fig. 5. The growth and emulsifying activity of $B$. licheniformis strain No. 5 as influenced by yeast extract or trace elements concentrations.

Additional medium optimization was attempted by adding different amounts of trace elements solution to the modified MSM (Fig. 5). The addition of $0.1 \%$ $(\mathrm{v} / \mathrm{v})$ trace element solution enhanced both the growth and emulsion index by $11.4 \%$ and $5.6 \%$, respectively $(1.681 \mathrm{~g} / \mathrm{l}, 45.45 \%)$. However, increasing the concentration of trace elements more than $0.1 \%$ resulted in a decrease in microbial growth and emulsification activity. Similarly, Reis et al. (2004) reported that the addition of trace minerals to the culture medium increased yield of lipopeptide surfactant produced by $B$. subtilis. The role of trace elements could be explained on the basis of their action as triggers for growth and consequently the liberation of more biosurfactant, that it is known that most of the trace elements perform their catalytic role as a constituent part of coenzymes. Thaniyavarn et al. (2006) found the addition of $1 \%$ of trace mineral solution was essential for the production of two kinds of lipopeptide biosurfactants, by $B$. licheniformis. Also, Verma et al. (2006) reported that Bacillus sp., Acinetobacter sp. and Pseudomonas sp. had the ability to produce biosurfactants when grown in MSM supplemented with $0.1 \%(\mathrm{v} / \mathrm{v})$ trace elements.

Egypt. J.Microbiol. 46 (2011) 


\section{Environmental conditions}

Incubation temperature and $\mathrm{pH}$ of production medium had a great effect on the growth and emulsification activity by B. licheniformis strain No. 5. While this bacterium grew and produced biosurfactant over all incubation temperatures tested, the greatest growth $(1.623 \mathrm{~g} / \mathrm{l})$ and emulsion index $(45.45 \%)$ were obtained at $30^{\circ} \mathrm{C}$ (Fig. 6). Increasing the incubation temperature more than $30^{\circ} \mathrm{C}$ inhibited both the growth and emulsification activity. This result is in accordance to many authors reports who stated that $30^{\circ} \mathrm{C}$ was the optimum incubation temperature for biosurfactant production (Haba et al., 2003; Thaniyavarn et al., 2003; Rashedi et al., 2005; Tabatabaee et al., 2005; Wei et al., 2005; Adelowo et al., 2006 and Chen et al., 2007). This may be related to the optimum growth temperature required by the tested microorganisms.

Results in Fig. 6 show the effect of different $\mathrm{pH}$ values on the growth and the biosurfactant production. B. licheniformis strain No. 5 grew and produced biosurfactant over the $\mathrm{pH}$ values ranged from 4 to 10 . The highest growth $(1.679 \mathrm{~g} / \mathrm{l})$ and emulsion index $(45.45 \%)$ were recorded at $\mathrm{pH}$ 7. By increasing $\mathrm{pH}$ more than 7, growth and emulsification activity were decreased, reaching their lowest values $(0.726 \mathrm{~g} / \mathrm{l}$ and $20.60 \%$, respectively) at $\mathrm{pH} 10$. Tabatabaee et al. (2005) indicated that Bacillus sp. could grow and produce biosurfactant at $\mathrm{pH}$ range (4.2-9.2) but maximum yield was recorded at $\mathrm{pH}$ range from 6.2-7.2.

\section{Biosurfactant production in bioreactor \\ Effect of different agitation rates}

Most biosurfactants are normally produced under highly aerobic conditions. This is achievable in their production by using aerated bioreactors (Kosaric, 1992). Oxygen seems to be a critical factor in biosurfactant production via its effect on enzymatic activities. A series of batch culture runs were performed with different agitation speeds to determine the optimum conditions for growth and biosurfactant production in the latest modified MSM. Both growth and biosurfactant production increased with increasing agitation speed, and reached their highest values at $300 \mathrm{rpm}$ (Fig. 7). The highest growth $(1.9 \mathrm{~g} / \mathrm{l})$ and emulsion index $(50.9 \%)$ were recorded at the $7^{\text {th }}$ day of incubation. Increasing agitation speed above $300 \mathrm{rpm}$ sharply decreased the growth and emulsification activity. Kosaric (1992) achieved high biosurfactant production in aerated bioreactors. Lin et al. (1994) found both the duration of the biosurfactant production phase and the maximum concentration was markedly higher in fermentations run with $30 \%$ DO concentration. On the other hand, when DO concentration was maintained at $85 \%$ of saturation, the production phase was barely detectable. 


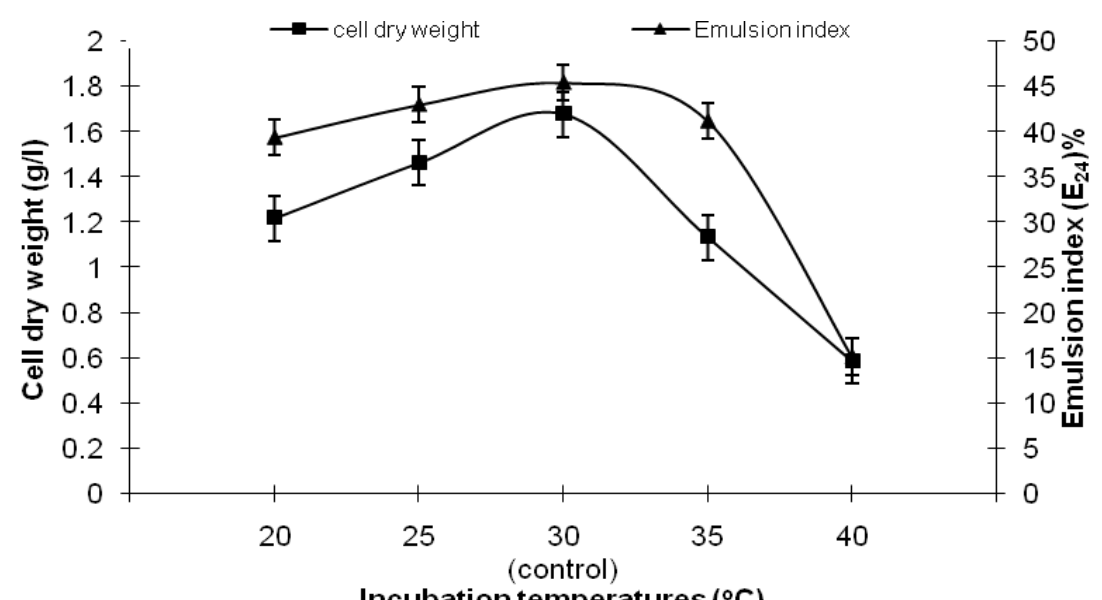

Incubation temperatures $\left({ }^{\circ} \mathrm{C}\right)$

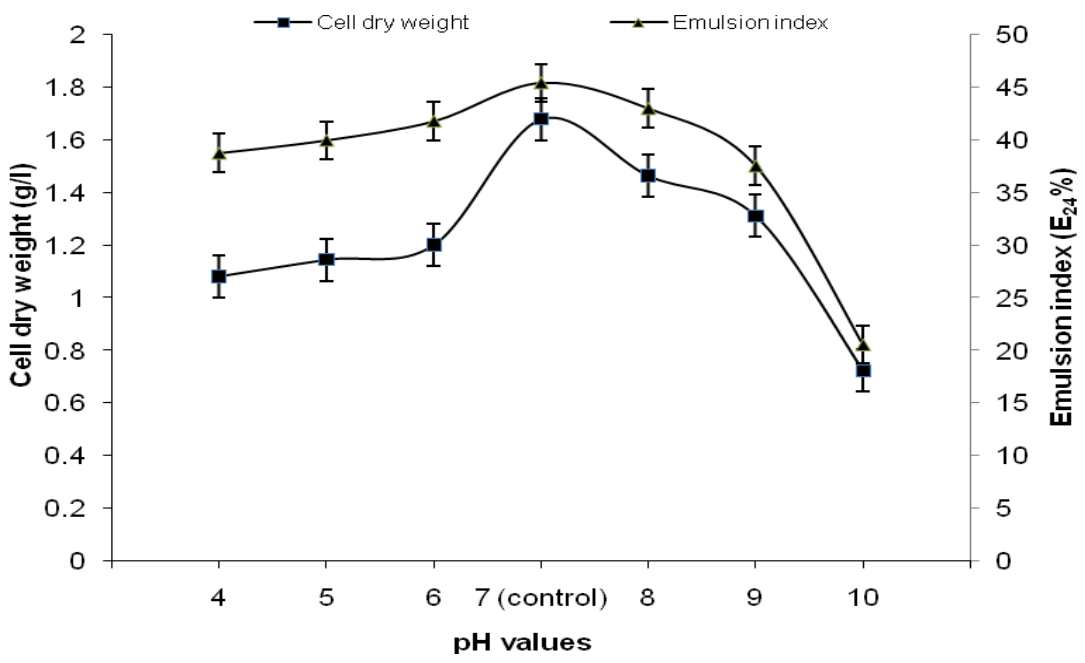

Fig. 6. Effect of incubation temperature or $\mathrm{pH}$ values on growth and emulsifying activity of $B$. licheniformis strain No. 5 . 


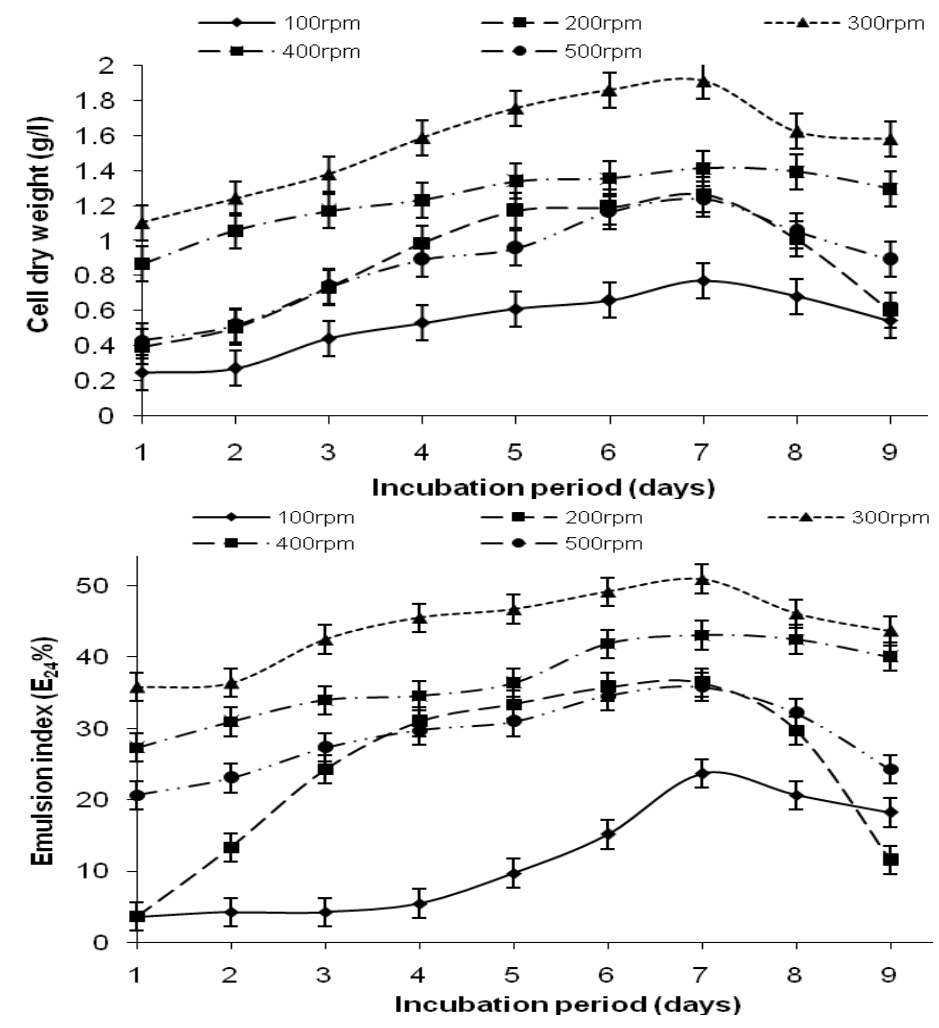

Fig. 7. Effect of different agitation rates on growth and emulsion index of $B$. licheniformis strain No. 5 during 9 days of incubation period using bioreactor.

Effect of pulsed supplementation of crude oil

The addition of $1 \%$ crude oil through the first two or three days of incubation period enhanced the emulsification activity $(67.27 \%)$ 1.3-fold compared to production with the entire amount of crude oil added at the beginning of culturing (Fig. 8). By increasing the supplementation period of crude oil, both the microbial growth and emulsification activity were decreased.

\section{Test of the emulsification strength using the crude biosurfactant}

Effect of different hydrocarbons and oils

The effect of the crude biosurfactant on different hydrocarbons and oils emulsions stabilization was studied (Fig. 9). The results showed that the most stable emulsion was obtained against diesel oil $\left(\mathrm{E}_{24}=87.27 \%\right)$ which almost remained stable for 10 days $\left(\mathrm{E}_{240}=81.8 \%\right)$. Other hydrocarbons and oils, like benzene, lubricating oil and sunflower oil achieved less stability. The highest emulsion index observed after $24 \mathrm{hr}$ was found with black grain oil $(89.1 \%)$ followed by diesel and sesame oils $(87.27 \%)$, and then by olive oil $(83.63 \%)$. Sifour et al. (2005) reported that the biosurfactant produced by $B$. licheniformis had a high activity against corn oil, it also had a good emulsification activity Egypt. J.Microbiol. 46 (2011) 
against sunflower oil, crude oil and waste oil. Manoj et al. (2007) also reported that the biosurfactant produced by $B$. licheniformis emulsified a range of hydrocarbons with hexadecane as the best substrate $\left(\mathrm{E}_{24}=71 \%\right)$ and toluene as the poorest one $\left(\mathrm{E}_{24}=12 \%\right)$.

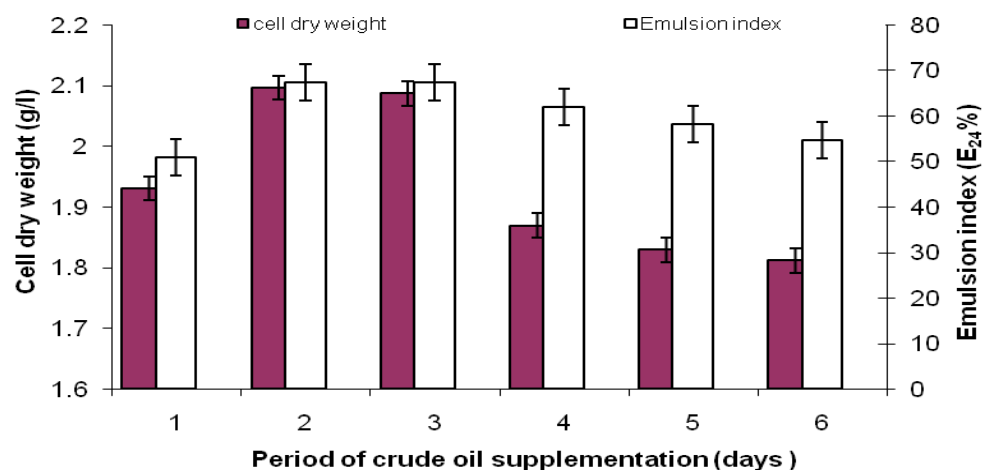

Fig. 8. Effect of pulsed supplementation of crude oil on growth and emulsifying activity of B. licheniformis strain No. 5 .

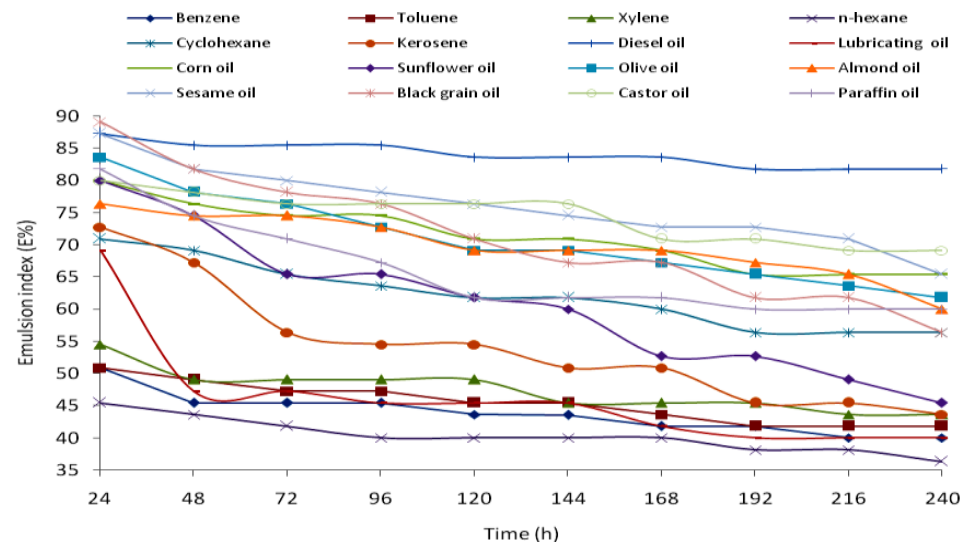

Fig. 9. Emulsion stabilizing effect of produced biosurfactant on different hydrocarbons and oils during ten days of incubation at $30^{\circ} \mathrm{C}$.

\section{Effect of $p H$}

The biosurfactant produced by $B$. licheniformis strain No. 5 showed an almost stable surface activity profile over a wide range of $\mathrm{pH}$ values (6 to 12 ). The maximum emulsification activity was obtained at $\mathrm{pH} \mathrm{8,} \mathrm{where} \mathrm{the} \mathrm{emulsion} \mathrm{index}$ was $87.3 \%$ and $50.9 \%$ against diesel oil and toluene, respectively (Fig. 10). Emulsification activity was slightly decreased at higher $\mathrm{pH}$ values. On the other hand, the biosurfactant attained lower emulsification activity at $\mathrm{pH}$ values from 2 to 4 . It was precipitated at $\mathrm{pH}$ values lower than $\mathrm{pH} 6$, therefore the emulsion index was decreased sharply. Milewski (2001) concluded that the precipitation of proteins took place at $\mathrm{pH}$ below 5 due to the fact that $\mathrm{pH}$ equaled the isoelectric 
point, and that there was no electrostatic repulsion between neighboring molecules, and they tend to coalesce and precipitate. In a similar study, Namir et al. (2009) showed that the surface-active compound produced by B. subtilis was stable during exposure a wide range of $\mathrm{pH}$ values (5.0-11.0). Similar results were obtained by Teixeira et al. (2009) who reported that the biosurfactant produced by $B$. licheniformis strain No. 5 was resistant at $\mathrm{pH}$ values ranging from 3 to 10 .
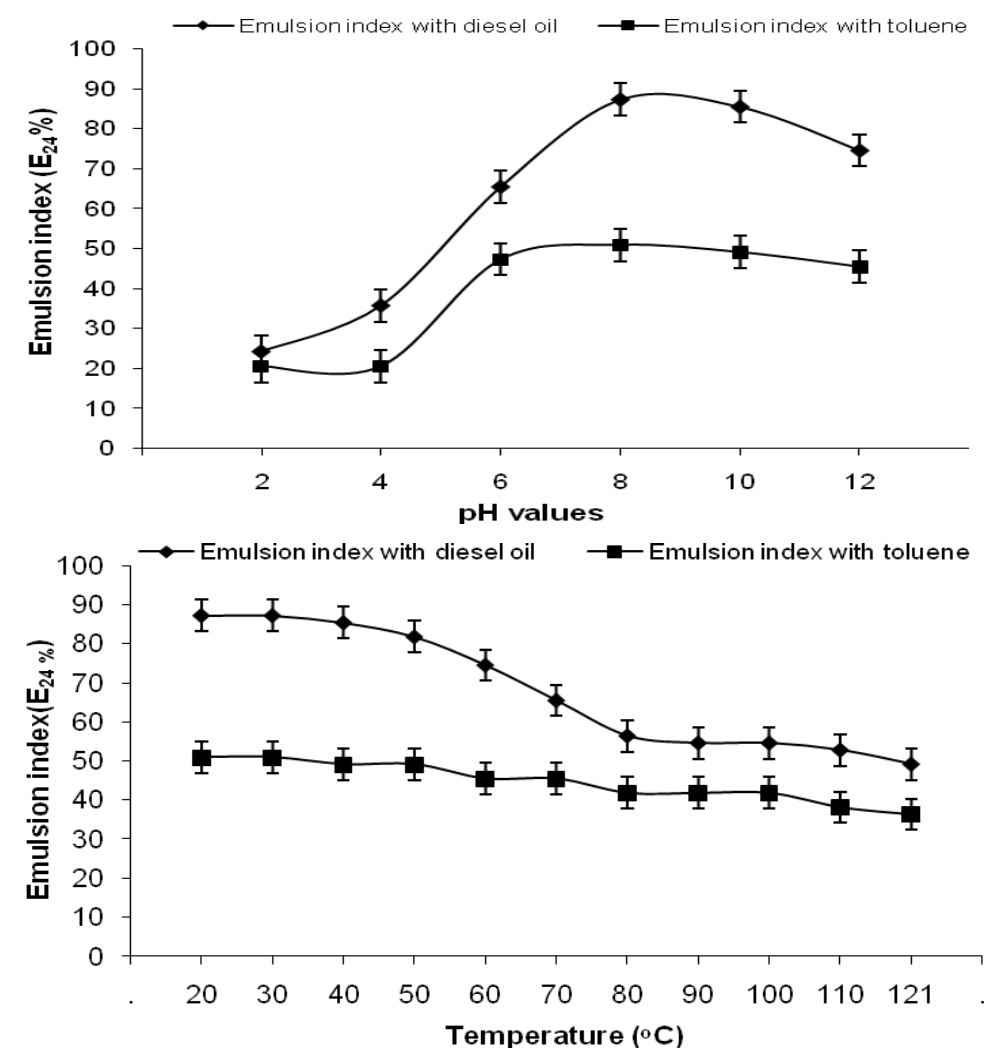

Fig. 10. Effect of pH values or temperature on the emulsification activity of the crude biosurfactant produced by $B$. licheniformis strain No. 5 .

\section{Effect of temperature}

The biosurfactant exposure to temperatures of $20^{\circ} \mathrm{C}$ or $30^{\circ} \mathrm{C}$ for $1 \mathrm{hr}$ did not alter the formation of emulsions against diesel oil and toluene (Fig. 10). Above $30^{\circ} \mathrm{C}$, low emulsions were obtained. The biosurfactant exhibited slight thermal stability upon exposure to $100^{\circ} \mathrm{C}$ for $1 \mathrm{hr}$ or by autoclaving at $121^{\circ} \mathrm{C}$ for $15 \mathrm{~min}$. The reduction in $\mathrm{E}_{24}$ obtained by biosurfactant exposed to $121^{\circ} \mathrm{C}$ for $15 \mathrm{~min}$ against diesel oil and toluene, was $43.7 \%$ and $28.6 \%$, respectively. Such reduction in emulsion index was greatly dependant on the type of emulsified hydrocarbon or oil used. Previous results indicated that the biosurfactant could emulsify different aliphatic, aromatic hydrocarbons, and vegetable oils and Egypt. J.Microbiol. 46 (2011) 
remained stable for 10 days at a wide range of $\mathrm{pH}$ and temperatures. Joshi et al. (2008) reported that the biosurfactants needs to be stable under the extreme environmental conditions encountered in an oil reservoir such as high temperature, pressure and salinity. They reported that the biosurfactant produced by $B$. licheniformis and $B$. subtilis strains retained its surface-active properties after incubation at $80^{\circ} \mathrm{C}$ for nine days. In another study, the biosurfactant produced by $B$. licheniformis was resistant for up to $100^{\circ} \mathrm{C}$ (Teixeira et al., 2009). Moreover, the surface-active compound produced by B. subtilis was stable during exposure to elevated temperature of $100^{\circ} \mathrm{C}$ (Namir et al., 2009).

\section{Chemical properties of the purified biosurfactant}

The chemical analysis of purified biosurfactant produced by B. licheniformis strain No. 5 indicated that it is a lipopeptide biosurfactant containing $41.76 \% \mathrm{C}$, $7.38 \% \mathrm{H}$ and $5.79 \% \mathrm{~N}$, composed of $36.2 \%$ protein, $12.3 \%$ lipids and $5.6 \%$ carbohydrates. Results of amino acids analyses of the peptide portion showed that the charged amino acids glutamate, lysine, aspartate and arginine were the dominant in the biosurfactant protein (Table 1). They represented 7.9, 7.3, 7.1 and $6.6 \%$, respectively. While, the lowest percentages of amino acids $(0.859$ and $1.452 \%$ ), were methionine and tyrosine, respectively.

TABLE 1. The amino acids content of the purified biosurfactant produced by $B$. licheniformis strain No. 5.

\begin{tabular}{|l|c|l|c|}
\hline \multicolumn{1}{|c|}{ Amino acids } & Content $(\boldsymbol{\%})$ & Amino acids & Content (\%) \\
\hline Asparagine & 7.116 & Methionine & 0.859 \\
\hline Therionine & 3.678 & Isoleucine & 4.733 \\
\hline Serine & 2.654 & Leucine & 6.050 \\
\hline Glutamine & 7.944 & Tyrosine & 1.452 \\
\hline Proline & 2.523 & Phenylalanine & 3.611 \\
\hline Glycine & 4.507 & Histidine & 2.578 \\
\hline Alanine & 4.833 & Lysine & 7.319 \\
\hline Valine & 4.853 & Arginine & 6.608 \\
\hline
\end{tabular}

An analysis of fatty acids indicated that the percentage of unsaturated fatty acids $(69.7 \%)$ was higher than the saturated fatty acids $(30.3 \%)$ (Table 2$)$. The saturated fatty acids were palmitic (C16:0), stearic (C18:0) and arachidic (C20:0), while the constituents of unsaturated fatty acids were palmitoleic (C16:1), oleic (C18:1), linoleic (C18:2), linolenic (C18:3) and gadoleic (C20:1). The major constituent of saturated fatty acids was palmitic acid (C16:0). It represented $(21.58 \%)$ of the extracted oil. Oleic acid was the most prevalent unsaturated fatty acid. It represented $(37.39 \%)$ of the extracted oil. Linoleic acid (C18:2) was the second major unsaturated fatty acid, its amount was (17.02\%). Youssef et al. (2005) indicated that the fatty acid composition of lipopeptide biosurfactants is important for their activity and that manipulation of the medium composition to change the composition of the lipopeptide fatty acids may result in biosurfactants with higher specific activities. 
TABLE 2. The fatty acids content of the purified biosurfactant produced by $B$. licheniformis strain No. 5.

\begin{tabular}{|cc|c|}
\hline \multicolumn{2}{|c|}{ Fatty acids } & Content (\%) \\
\hline Palmitic & $(\mathrm{C} 16: 0)$ & 21.58 \\
\hline Palmitoleic & $(\mathrm{C} 16: 1)$ & 5.76 \\
\hline Stearic $\quad(\mathrm{C} 18: 0)$ & 5.49 \\
\hline Oleic $\quad(\mathrm{C} 18: 1)$ & 37.39 \\
\hline Linoleic $\quad(\mathrm{C} 18: 2)$ & 17.02 \\
\hline Linolenic $\quad(\mathrm{C} 18: 3)$ & 2.41 \\
\hline Arachidic $\quad(\mathrm{C} 20: 0)$ & 3.21 \\
\hline Gadoleic $\quad(\mathrm{C} 20: 1)$ & 7.10 \\
\hline
\end{tabular}

Total percentage of saturated fatty acids $=30.28 \%$.

*Total percentage of unsaturated fatty acids $=69.68 \%$.

\section{Conclusion}

A local bacterium, B. licheniformis strain No. 5, was considered to be an efficient biosurfactant producer in either batch or fed-batch cultures. The agitation of the culture at $300 \mathrm{rpm}$ was efficient to sustain a balanced aeration rate in batch culture. In fed-batch culture, the pulsed addition of crude oil during the first two or three days of incubation enhanced the emulsification activity by 1.3-fold. The biosurfactant emulsified different aliphatic, aromatic hydrocarbons, and vegetable oils. It also emulsified organic hydrocarbons more efficiently than mineral hydrocarbons. The results showed the ability of the detected biosurfactant to promote emulsification of different hydrocarbons and oils under temperature and $\mathrm{pH}$ stresses. The stability of the biosurfactant produced at different temperature and $\mathrm{pH}$ is an important issue that can affect its application spectrum. These properties make it a potential candidate to be used in bioremediation of contaminated sites and in the petroleum industry where drastic conditions commonly prevail.

\section{References}

A.O.A.C. (1990) "Official Methods of Analysis of the Association of Official Analytical Chemists". $15^{\text {th }}$ ed. Association of Official Analytical Chemists. Arlington, Virginia, USA.

Adelowo, O.O., Alagbe, S.O. and Ayandele, A.A. (2006) Time-dependent stability of used engine oil degradation by cultures of Pseudomonas fragi and Achromobacter aerogenes. Afr. J. Biotechnol. 5, 2476-2479.

Banat, I.M. (1995) Biosurfactants production and possible uses in microbial enhanced oil recovery and oil pollution remediation. A review. Bioresour. Technol. 51, 1-12.

Bognolo, G. (1999) Biosurfactants as emulsifying agents for hydrocarbons. Coll. Surf. 152, 41-52. 
Bonilla, M., Olivaro, C., Corona, M., Vazquez, A. and Soubes, M. (2005) Production and characterization of a new bioemulsifier from Pseudomonas putida ML 2. J. Appl. Microbiol. 98, 456-463.

Cameotra, S.S. and Makkar, R.S. (2004) Recent applications of biosurfactants as biological and immunological molecules. Curr. Opin. Microbiol. 7, 262-266.

Chaplin, M.F. and Kennedy, J.F. (1994) "Carbohydrate Analysis-A Practical Approach". $2^{\text {nd }}$ ed. Oxford University Press, Oxford, New York. Tokyo. pp. 324.

Chen, S.Y., Lu, W.B., Wei, Y.H., Chen, W.M. and Chang, J.S. (2007) Improved production of biosurfactant with newly isolated Pseudomonas aeruginosa S2. Biotechnol. Prog. 23, 661-666.

Deziel, E., Paquette, G., Villemur, R., Lepine, F. and Bisaillon, J.G. (1996) Biosurfactant production by a soil Pseudomonas strain growing on polycyclic aromatic hydrocarbons, Appl. Environ. Microbiol. 62, 1908-1912.

Haba, E., Espuny, M.J., Busquets, M. and Manresa, A. (2000) Screening and production of rhamnolipids by Pseudomonas aeruginosa 47T2 NCIB 40044 from waste frying oil. J. Appl. Microbiol. 88, 379-387.

Haba, E., Pinazo, A., Jauregui, O., Espuny, M.J., Infante, M.R. and Manresa, A. (2003) Physicochemical characterization and antimicrobial properties of rhamnolipids produced by Pseudomonas aeruginosa 47T2 NCBIM 40044. Biotechnol. Bioeng. 81, $316-322$.

Haddadin, M.S.Y., Abou Arqoub, A.A., Abu Reesh, I. and Haddadin, J. (2009) Kinetics of hydrocarbon extraction from oil shale using biosurfactant producing bacteria. Energ. Convers. Manag. 50, 983-990.

Jonathan, D.V.H. and Urban, J. (2003) Biosurfactants in bioremediation. In: "Advances in Applied Bioremediation”. Singh, A.; Ramesh, C.; Kuhad, C. and Ward, O.P. (Ed.) pp. 73-89. Springer, Berlin, Heidelberg.

Joshi, S., Bharucha, C. and Desai, A.J. (2007) Production of biosurfactant and antifungal compound by fermented food isolate Bacillus subtilis 20B. Bioresour. Technol. 99, 4603-4608.

Joshi, S., Bharucha, C., Jha, S., Yadav, S., Nerurkar, A. and Desai, A.J. (2008) Biosurfactant production using molasses and whey under thermophilic conditions. Bioresour. Technol. 99, 195-199.

Kanga, S.H., Bonner, J.S., Page, C.A., Mills, M.A. and Autenrieth, R.L. (1997) Solubilization of naphthalene and methyl-substituted naphthalenes from crude oil using biosurfactants. Environ. Sci. Technol. 31, 556-561.

Kim, H.S., Yoon, B.D., Lee, C.H., Suh, H.H., OH, H.M., Katsuragi, T. and Tani, Y. (1997) Production and properties of a lipopeptide biosurfactant from Bacillus subtilis C9. J. Ferment. Bioengin. 84, 41-46.

Kosaric, N. (1992) Biosurfactants in industry. Pure Appl. Chem. 64, 1731-1737. 
Krepsky, N., Silva, F.S., Fontana, L.F. and Crapez, M.A.C. (2007) Alternative methodology for isolation of biosurfactant-producing bacteria. Braz. J. Biol. 67, 117-124.

Le Duc, D.L., Tarun, A.S., Montes-Bayon, M., Meija, J. and Malit, M.F. (2004) Overexpression of selenocysteine methyltransferase in Arabidopsis and Indian mustard increases selenium tolerance and accumulation. Plant Physiol. 135, 377-383.

Lin, S.C., Carswell, K.S., Sharma, M.M. and Georgiou, G. (1994) Continuous production of the lipopeptide biosurfactant of Bacillus licheniformis JF-2. Appl. Microbiol. Biotech. 41, 281-285.

Makkar, R.S. and Cameotra, S.S. (2002) An update on the use of unconventional substrates for biosurfactant production and their new applications. Appl. Microbiol. Biotechnol. 58, 428-34.

Manoj, K., Leon, V., Sisto, M., Leon, A. and Ilzins, O.A. (2007) A halotolerant and thermotolerant Bacillus sp. degrades hydrocarbons and produces tensio-active emulsifying agent. World J. Microbiol. Biotechnol. 23, 211-220.

Milewski, S. (2001) Protein structure and physicochemical properties. In: "Chemical and Functional Properties of Food Proteins". Sikorski, Z.E. (Ed) pp. 35-55. Tech-nomic Publishing Company, Inc. Pennsylvania.

Mulligan, C.N. (2005) Environmental applications for biosurfactants. Environ. Pollut. 133, 183-198.

Mulligan, C.N. and Gibbs, B.F. (1993) Factors influencing the economics of biosurfactants. In: Biosurfactants, Production, Properties, Applications. Kosaric, N. (Ed.), pp. 329-371. Marcel Dekker, New York .

Namir, H. I. A., Wang, J. I. and Bozhong, M.U. (2009) Identification of a biosurfactant producing strain: Bacillus subtilis HOB2. Protein Peptide Lett. 16, 7-13.

Nitschke, M. and Pastore, G.M. (2006) Production and properties of a surfactant obtained from Bacillus subtilis grown on cassava wastewater. Bioresour. Technol. 97, 336-341.

Parks, L.C. (1997) “Handbook of Microbiological Media”. Atlas, R.M. (Ed.), p. 938. CRC Press, Boca Raton, New York.

Patel, M.N. and Gopinathan, K.P. (1986) Lysozyme-sensitive bioemulsifier for immiscible organophosphorus pesticides. Appl. Environ. Microbiol. 52,1224-1226.

Pellet, P.L. and Young, V.R. (1980) “Nutritional Evalution of Protein Foods". Published by the United Nation Univ. p. 189.

Ramadan, E.M., Kheiralla, Zeinb M., Foaad, M.A., EL-Tayeb, T.S. and Goma, Eman Z. (2010) Biosurfactant producing bacteria from oil contaminated Egyptian soil. Egypt. J. Microbiol, 45.

Rashedi, H., Jamshidi, E., Mazaheri, M. and Bonakdarpour, B. (2005) Isolation and production of biosurfactant from Pseudomonas aeruginosa isolated from Iranian southern wells oil. Int. J. Environ. Sci. Tech. 2, 121-127.

Egypt. J.Microbiol. 46 (2011) 
Reis, F.A.S.L., Servulo, E.F.C. and Franca, F.P. (2004) Lipopeptide surfactant production by Bacillus subtilis grown on low-cost raw materials. Appl. Biochem. Biotech. 115, 899-912.

Rismani, E., Fooladi, J. and Ebrahimi Por, G.H. (2006) Biosurfactant production in batch culture by a Bacillus licheniformis isolated from the Persian Gulf. Pakistan J. Biological Sci. 9, 2498-2502.

Rocha, C., San-Blas, F., San-Blas, G. and Vierma, L. (1992) Biosurfactant production by two isolates of Pseudomonas aeruginosa. World J. Microbiol. Biotech. 8, 125-128.

Rosenberg, E. and Ron, E.Z. (1998) Surface active polymers from the Genus Acinetobacter. In: “Biopolymers from Renewable Resources". Kaplan D.L. (Ed.), pp. 281-291, Springer, Berlin Heidelberg. New York.

Sattler, W., Reicher, H., Ramos, P., Panzenboeck, U., Hayn, M., Esterbauer, H., Maile, E. and Kostner, G.M. (1996) Preparation of fatty acid methyl esters from lipoprotein and macrophage lipid subclasses on Thin-Layer Plates. Lipids, 31, 13031310 .

Sepahy, A.A., Assadi, M.M., Saggadian, V. and Noohi, A. (2005) Production of biosurfactant from Iranian oil fields by isolated Bacilli. Int. J. Environ. Sci. Technol. 1, 287-293.

Sifour, M., Ouled-Haddar, H. and Aziz, G.M. (2005) Production of biosurfactants from two Bacillus species. Egypt. J. Aquatic Res. 31, 142-148.

Tabatabaee, A., Assadi, M.M., Noohi, A.A. and Sajadian, V.A. (2005) Isolation of biosurfactant producing bacteria from oil reservoirs. Iran. J. Env. Health Sci. Eng. 2, $6-12$.

Teixeira, M.L., Olivera, F.C., Santos, J.D. and Brandelli, A. (2009) Purification and characterization of a peptide from Bacillus licheniformis showing dual antimicrobial and emulsifying activities. Food Res. Int. 42, 63-68.

Thaniyavarn, J., Chongchin, A., Wanitsuksombut, N., Thaniyavarn, S., Pinphanichakarn, P., Eepipatpiboon, N., Morikawa, M. and Kanaya, S. (2006) Biosurfactant production by Pseudomonas aeruginosa A 41 using palm oil as carbon source. J. Gen. Appl. Microbiol. 52, 215-222.

Thaniyavarn, J., Roongsawang, N., Kameyama, T., Haruki, M., Imanaka, T., Morikawa, M. and Kanaya, S. (2003) Production and characterization of biosurfactants from Bacillus licheniformis F2.2. Biosci. Biotechnol. Biochem. 67, 1239- 1244.

Turkovskaya, O.V., Dmitrieva, T.V. and Muratova, A.Y. (2001) A biosurfactant producing Pseudomonas aeruginosa strain. Appl. Biochem. Microbiol. 37, 71-75.

Verma, S., Bhargava, R. and Pruthi, V. (2006) Oily sludge degradation by bacteria from Ankleshwar, India. Int. Biodeterior. Biodegrad. 57, 207-213.

Walzer, G., Rosenberg, E. and Ron, E.Z. (2006) The Acinetobacter outer membrane protein A (OmpA) is a secreted emulsifier. Environ. Microbiol. 8, 1026-1032 
Wei, Y.H., Chou, C.L. and Chang, J.S. (2005) Rhamnolipid production by indigenous Pseudomonas aeruginosa J4 originating from petrochemical wastewater. Biochem. Engin. J. 27, 146-154.

Youssef, N.H., Duncan, K.E and McInerney, M.J. (2005) Importance of 3-hydroxy fatty acid composition of lipopeptides for biosurfactant activity. Appl. Environ. Micrbiol. 71, 7690-7695.

(Received 6/ 4/ 2010; accepted 27/6/2010)

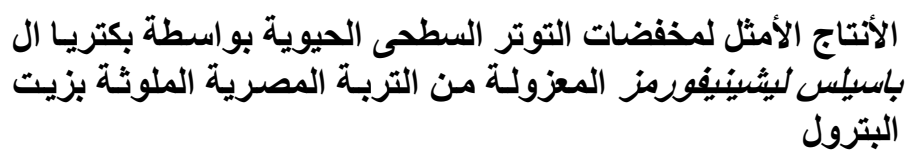

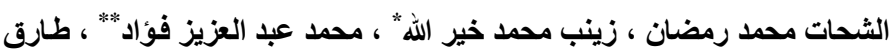

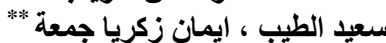

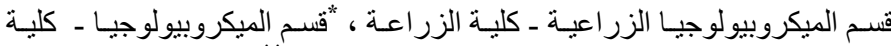

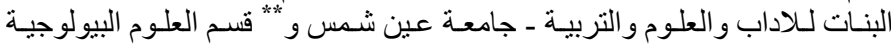

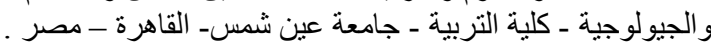

تم در اسة الظروف المثلى لأقصى انتاج لمخفضات التوتر السطحى بو اسطة سلالة

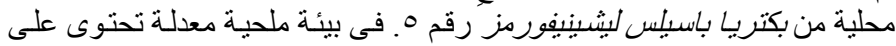

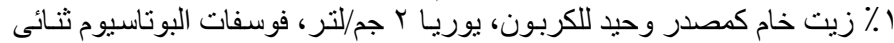

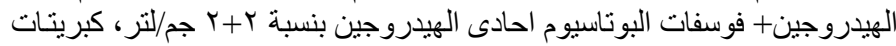

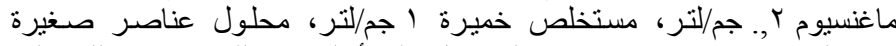

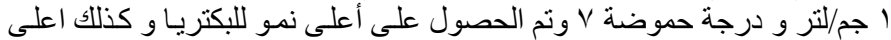

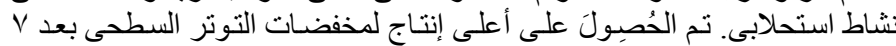

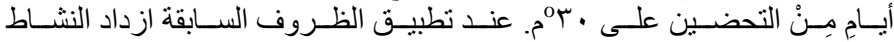

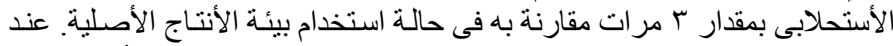

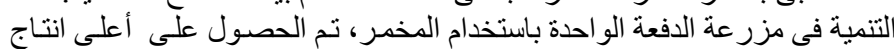

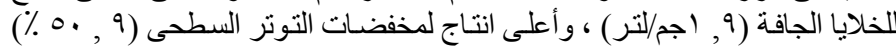

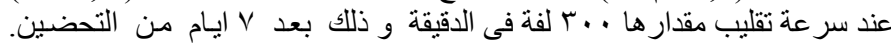

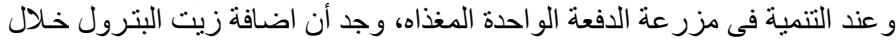

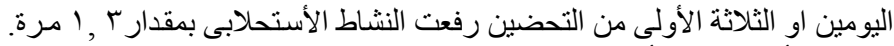

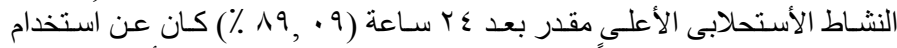

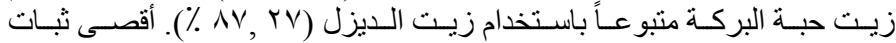

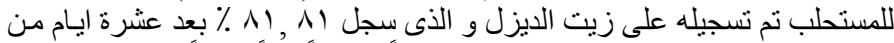

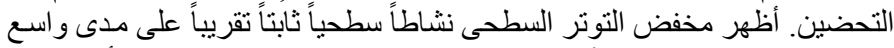

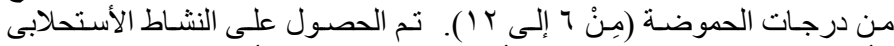

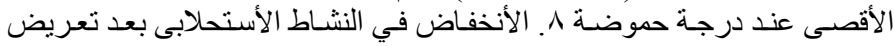

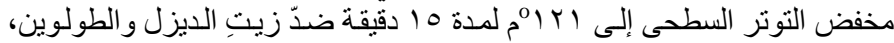

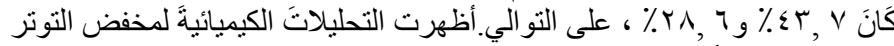

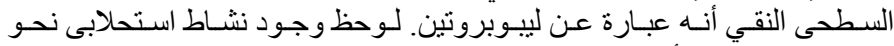

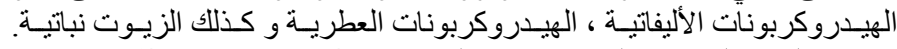

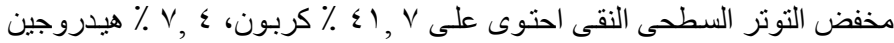

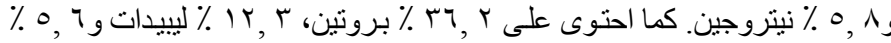
كربو هيدر ات.

Egypt. J.Microbiol. 46 (2011) 